\title{
O ACESSO DE ALUNOS DE ESCOLAS PÚBLICAS AO CIRCUITO LIBERDADE: ANÁLISE DE UM PROJETO PILOTO*
}

\author{
Ana Flávia Machado** \\ Universidade Federal de Minas Gerais (CEDEPLAR/FACE/UFMG), Belo Horizonte - MG, Brasil \\ Bárbara Freitas Paglioto*** \\ Universidade Federal de Minas Gerais (CEDEPLAR/FACE/UFMG), Belo Horizonte - MG, Brasil \\ Maria Helena Cunha**** \\ Universidade Federal de Minas Gerais (FAE/UFMG), Belo Horizonte - MG, Brasil
}

RESUMO: Este artigo se propõe a descrever a relação entre o acesso de alunos de escolas públicas a equipamentos culturais e seu perfil socioeconômico e hábitos formados e cultivados no âmbito de práticas culturais. Para tal, foi feita uma pesquisa de campo junto a escolas da rede pública de ensino de Belo Horizonte. Formaram-se dois grupos de alunos entrevistados, os que participaram da ação educativa e os que não participaram. Buscouse captar o efeito desse programa, considerando perfil demográfico do aluno, preferências por disciplinas e lugares dentro da escola, condições socioeconômicas da família, hábitos culturais, alocação de tempo e avaliação de Belo Horizonte. Os resultados evidenciam que os alunos mais motivados pelo contato com o Circuito Liberdade são aqueles mais interessados nas atividades escolares, assim como aqueles que informam frequentar e participar de atividades culturais.

Palavras-chave: Hábitos. Cultura. Museu. Educação.

http://dx.doi.org/10.1590/0102-4698150065

* Esta pesquisa foi financiada CNPq/MinC por meio da Chamada n. 80/2013 CNPq/SEC/MinC. 0 campo foi autorizado pelo COEP-UFMG em 6 de outubro de 2014.

${ }^{*}$ *Doutora em Economia pela Universidade Federal do Rio de Janeiro (UFRJ). Professora Associada do Departamento de Ciências Econômicas da Universidade Federal de Minas Gerais (UFMG). Coordenadora do Grupo de Pesquisas em Economia da Cultura no CNPq. E-mail: < afmachad@cedeplar.ufmg.br >.

*** Mestre em Economia pelo Centro de Desenvolvimento e Planejamento Regional (CEDEPLAR) da Universidade Federal de Minas Gerais (UFMG). Assessora do Núcleo de Educação, Acessibilidade e Pesquisa do Espaço do Conhecimento da Universidade Federal de Minas Gerais (UFMG). Membro do Grupo de Pesquisa em Economia da Cultura da Universidade Federal de Minas Gerais (UFMG). E-mail: <bfpaglioto@gmail.com>.

**** Mestre em Educação pela Faculdade de Educação (FAE) da Universidade Federal de Minas Gerais (UFMG), Especialista em Planejamento e Gestão Cultural pela Pontifícia Universidade Católica de Minas Gerais (PUC/MG) e proprietária da Inspire Gestão Cultural. E-mail: < lenacunha@inspirebr.com.br > . 


\section{PUBLIC SCHOOLS' ACCESS TO CIRCUITO LIBERDADE: A PILOT PROJECT'S ANALYSIS}

ABSTRACT: This paper aims to describe the relationship between the public schools students' access to cultural equipments, socioeconomics profile and cultural habits. We have conducted a survey in several public schools in the city of Belo Horizonte-MG. Students participated in a program where they visited Circuito Liberdade (CL), a group of buildings that offers a wide range of cultural events. By comparing two groups, we sought to analyze the program's effects, taking into consideration student's demographic profile, their preferences for subjects, favorite places in their school's premises, family background, cultural habits, free time allocation and their views about the city itself. A questionnaire about their personal view on the visit to the cultural complex was also conducted. The results suggest that students more motivated for visiting CL are more motivated to study and to visit the CL again.

Keywords: Habits. Culture. Museum. Education.

\section{A VISITA DA ESCOLA AO MUSEU: EFEITOS SOBRE FORMAC̣ÃO DE PÚBLICO}

Na obra O Lugar do público - sobre o uso de estudos e pesquisas pelos museus, Jacqueline Eidelman e Mélanie Roustan (2014) mostram que, desde o final do século XIX, são feitas pesquisas sobre a relação entre o museu e o público. No início do século XX, a temática se concentrava no acesso às exposições, tanto em museus de arte quanto nos de ciência, focando primeiro nos visitantes desacompanhados, depois nos grupos escolares (JANCHERY; PRAET, 2014). Já nesse período, a preocupação com o público escolar mostrava-se presente tanto em relação às contribuições de uma preparação para a visita quanto sobre os efeitos da visita na obtenção de conhecimentos escolares.

As ações de formação e educação de crianças e adolescentes nos diversos programas de museus configuram agenda relevante de boa parte desses equipamentos. A educação e a cultura são dois aspectos que, interconectados, indicam, em grande medida, o desenvolvimento socioeconômico de uma população. As ações culturais contribuem para a formação de um indivíduo e, por extensão, para a formação de um consumidor de atividades culturais, por envolverem atividades em que alguma forma de criatividade se faz presente em sua produção e por se voltarem para geração e comunicação de significados simbólicos.

Yúdice (2006) resgata o sentido molecular de Deleuze, com estrutura flexível, e sugere um novo modelo de museus, em que o objetivo principal é produzir novas estruturas que possam dar lugar 
a formas inéditas de articulação de processos artísticos e processos sociais, tornando o público um sujeito capaz de fazer intervenções e formular hipóteses, de favorecer a capacidade de ação e de superar as limitações das divisões tradicionais entre ator e espectador, produtor e consumidor. Nessa mesma linha de raciocínio, Nascimento (2013) afirma que, para além de obras arquitetônicas, os museus, por meio de seus gestores, têm buscado se constituir em um espaço de discussão e de formação de conhecimento. E, nesse particular, as ações educativas que envolvem a interação entre museu e escolas são desenvolvidas.

O conceito de capital cultural proposto por Bourdieu e Darbel (1969), por sua vez, relaciona o aprendizado familiar e a sua consolidação pela escola ao comportamento das pessoas frente às atividades culturais consideradas legítimas (como música clássica, teatro e literatura). Como bem lembra Benhamou (2007), reportandose a esse conceito, o gosto pelas "artes" não é nato, depende de conversas, de referências, de viagens que são realizadas no âmbito familiar e reforçadas pelas escolas e instituições afins. Nas palavras de Benhamou (2007, p. 28), "o aprendizado cultural reside nessa perspectiva do contato repetido, [...] tanto com as obras quanto com aqueles que aprenderam a frequentá-la”.

No âmbito das Ciências Econômicas, mais propriamente, no interesse de formação de público, o modelo consolidado de descrição da formação de hábitos culturais seria o proposto por Stigler e Becker (1977), que relacionam a ideia de "vício positivo" à apreciação e ao consumo de bens e serviços culturais. Isto é, os indivíduos valorizam manifestações culturais no presente, porque foram expostos no passado à sua apreciação. Há uma relação, portanto, de complementaridade entre o consumo presente e o passado.

Dessa forma, a formação de público, pelo ponto de vista das políticas públicas para a cultura e a educação, deve ser analisada a partir das possibilidades criadas para democratizar o acesso do cidadão aos bens e serviços culturais, o que não significa apenas a oferta de eventos ou a entrada em espaços gratuitos ou subsidiados, mas que também deve ser vista a partir de um processo de educação formal, ou não, que proporcione ao cidadão o acesso ao conhecimento. E é esse domínio mínimo dos códigos culturais que pode garantir o direito de escolha sobre o desejo de frequentar, ou não, ambientes culturais e, consequentemente, de fazer parte de seus hábitos cotidianos.

Assim, tanto na perspectiva econômica quanto na sociológica, há um consenso de que, para se tornar um indivíduo capaz de apreciar, consumir e, mesmo em algum sentido, produzir atividades 
culturais, é necessário expô-lo a tal, tendo-se a família e a escola como principais indutores.

No intuito de analisar os efeitos dos programas e ações de equipamentos culturais sobre a formação de público escolar, escolheu-se o caso do Circuito Liberdade (CL). Tal circuito se localiza na área central de Belo Horizonte e conta com vários espaços culturais (Quadro 1). A governança é público-privada e, além da própria gestão do CL, alguns espaços organizam programas específicos de visitação de alunos, especialmente de escolas públicas. Esse público específico representa, para vários dos espaços culturais, parcela bastante significativa dos visitantes.

QUADRO 1 - Equipamentos do Circuito Liberdade

\section{Equipamento}

Arquivo Público Mineiro

Biblioteca Pública Estadual Luiz de Bessa

Casa da Economia Criativa

Casa Fiat de Cultura

Centro Cultural Banco do Brasil

Centro de Arte Popular

Centro de Formação Artística (CEFAR)

Espaço do Conhecimento

Memorial Minas Gerais Vale

Museu de Minas e Metais

Museu do Palácio da Liberdade

Museu Mineiro

\section{Gestão}

Pública estadual

Pública estadual

SEBRAE

FIAT Automóveis

Banco do Brasil

CEMIG

Fundação Clóvis Salgado

UFMG

VALE

GERDAU

Pública estadual

Pública estadual 
FOTOGRAFIA 1 - Vista aérea da Praça da Liberdade e de espaços do Circuito Liberdade

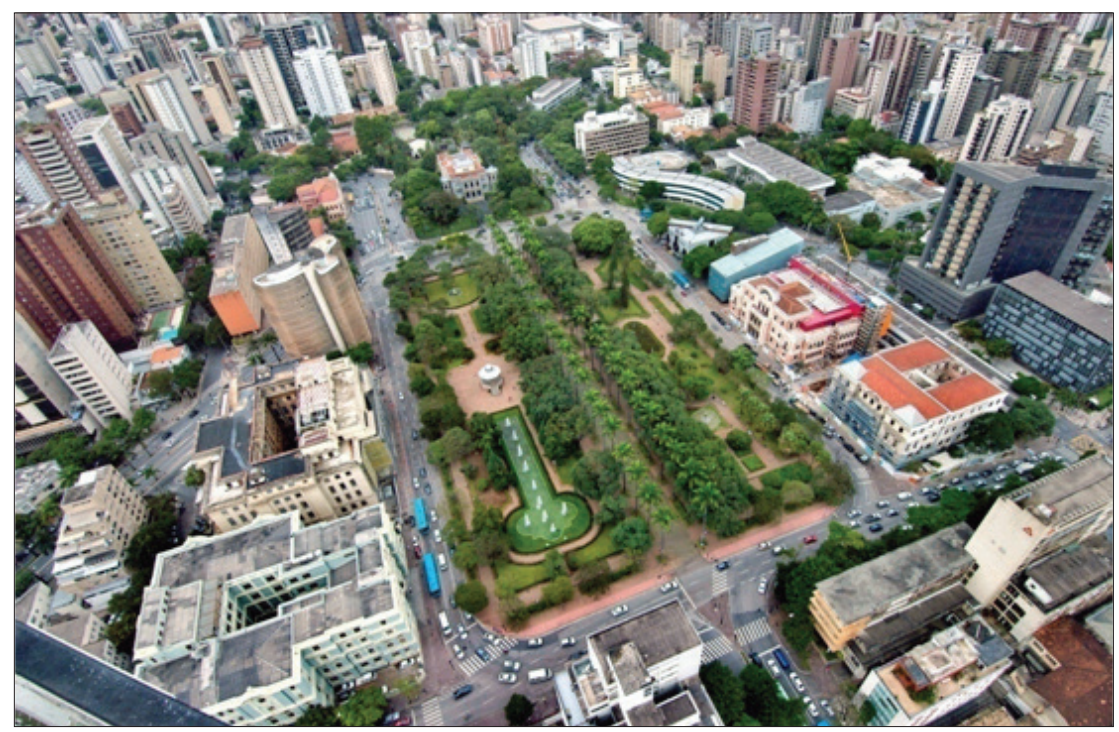

Foto: Lucia Sebe. Portal PBH. (Todos os direitos reservados). ${ }^{1}$

Este estudo faz parte de um projeto piloto para a elaboração e experimentação de uma metodologia capaz de captar os efeitos dessas visitas educativas a museus e espaços culturais, sobre os hábitos culturais de alunos de escolas públicas.

Para alcance desse objetivo, foram convidadas escolas que já haviam participado de algum programa educativo de um ou mais dos espaços do CL. Em cada uma delas, foi feita a aplicação de questionários junto a alunos que participaram - e que não participaram (grupo controle) - das visitas aos espaços culturais. Os principais resultados dessa pesquisa são descritos neste artigo que conta com cinco seções, considerando esta, contextualizando o problema. A segunda traz aspectos da amostra analisada que não é representativa para o conjunto da população escolar, mas que é expressiva em termos do perfil do visitante nessa modalidade. As características socioeconômicas dos alunos são apresentadas na terceira seção. Em seguida, relacionam-se gostos e hábitos à experiência da visita e analisam-se, como contraponto, os resultados das perguntas sobre hábitos culturais do questionário do Sistema de Avaliação do Ensino Básico (SAEB), feitas às professoras de $9^{\circ}$ ano do Ensino Fundamental e, por fim, na quinta seção, são feitas algumas considerações. 


\section{ASPECTOS METODOLÓGICOS DO PROJETO PILOTO}

A seleção das escolas foi, a princípio, aleatória, considerando as que tinham participado de algum dos programas de visitação, assim como uma distribuição espacial que refletisse a heterogeneidade presente na cidade de Belo Horizonte, particularmente a advinda da desigual distribuição de rendimentos. Assim, a distribuição geográfica das escolas onde ocorreram a aplicação dos questionários deveria refletir a variabilidade na distribuição de renda e das variáveis socioeconômicas do município.

MAPA 1 - Localização das escolas participantes no município de Belo Horizonte

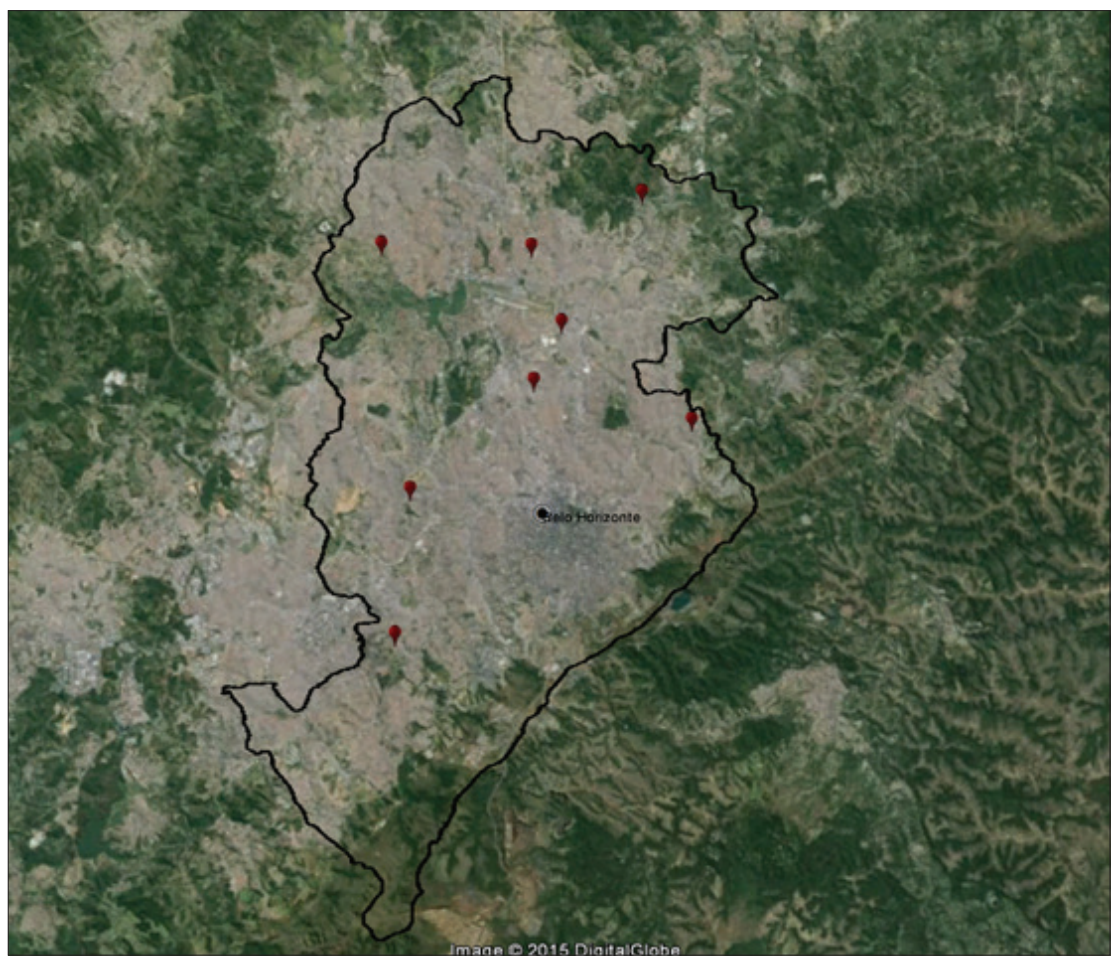

Fonte: Elaboração pelos autores deste artigo a partir de imagens do Google Earth.

A referência para definição das escolas a serem selecionadas foi a lista de escolas visitantes informada pela gestão do CL. Considerando o perfil sociodemográfico das áreas selecionadas, como acima explicado, foi feito contato com as diretoras das escolas nelas localizadas. A seleção final das escolas pesquisadas é uma combinação de três fatores: escolas que aceitaram participar da pesquisa, escolas 
cujos professores não estavam em greve e escolas que ainda contavam com os alunos que haviam realizado a visita.

Em um segundo nível, foram entrevistados alunos com idade acima de 13 anos. Tal clivagem se justifica pela maturidade requerida para responder às questões. Nesse grupo de alunos, foi feita uma segunda estratificação ad hoc (pelas professoras) para formar um grupo de tratamento (10 alunos de cada escola entre aqueles que visitaram o CL) e de controle (10 alunos entre os que não o fizeram). Dividir os alunos em dois grupos, segundo o critério da visita, é um mecanismo que busca, indiretamente, captar o efeito da visita sobre a formação de público.

Foram dois os tipos de questionários aplicados (Anexos A e B). O mais sintético, direcionado aos alunos que não visitaram o Circuito Liberdade, traz perguntas referentes ao perfil demográfico dos alunos, às preferências por disciplinas e lugares dentro da escola, às condições socioeconômicas da família, a hábitos culturais, à alocação de tempo livre, à avaliação de Belo Horizonte e de seus problemas, às razões de não ter visitado o Circuito Liberdade. O questionário extenso - voltado para os alunos que fizeram a visita - incorpora todos os módulos acima citados, além de um sobre a visita e seus possíveis impactos, perguntando quais espaços conheceu, sobre a avaliação desses locais, a idade à época da visita e a série que frequentava, se já conhecia o Circuito Liberdade antes de ir com a escola, se voltou depois da visita e se a ela tinha deixado alguma marca, entre outras questões.

As perguntas referentes a hábitos culturais seguem o referendado pela literatura, inclusive no Brasil (IBGE, 2008; KÖPTCKE; KÖPTCKE, 2008, 2012; CPIM; DEPMUS; IBRAM, 2012). Ainda que seja consenso perguntar sobre frequência a concertos, teatros, salas de cinemas, museus, entre outras atividades culturais, além de leitura de livros, buscando captar se o indivíduo é ou não consumidor de cultura, tem ou não hábito cultural, as perguntas que replicamos nos questionários deste estudo não são capazes de dimensionar manifestações culturais de caráter mais popular. Nessas, o impulso coletivo tende a predominar, por meio de rodas de samba, congados, bailes funk, entre outros. Frequentar concerto, museus, centros culturais é algo cuja referência é centrada em um perfil de consumidor europeu, uma vez que a maioria dos estudos sobre demanda por cultura é proveniente de institutos e universidades de países europeus. Sendo assim, alguns dos achados deste estudo podem estar enviesados pelo conceito de atividade cultural empregado. 


\section{PERFIL DOS VISITANTES E NÃO VISITANTES ENTRE ALUNOS DE ESCOLAS PÚBLICAS}

Do total de 160 alunos contatados, 154 aceitaram responder ao questionário. Conforme a Tabela 1, abaixo, a distribuição dos alunos segundo espaço visitado evidencia que 57,3\% deles estiveram no Museu de Minas e Metais, seguido pela Biblioteca Pública, 36\%. De todos, o menos visitado pelos alunos de escola pública é o Arquivo Mineiro, provavelmente, porque se tratam de crianças e adolescentes e o acervo desse espaço se volta mais à pesquisa documental, historiográfica, bibliográfica e, em grande parte, de cunho acadêmico.

TABELA 1 - Ordenação dos espaços por número de alunos da amostra que os visitaram

\begin{tabular}{llcc}
\hline & Espaço & Número de alunos que visitaram & $\%$ \\
\hline 1 & Museu de Minas e Metais & 43 & 57,3 \\
2 & Biblioteca Pública Estadual Luiz de Bessa & 27 & 36,0 \\
3 & Museu do Palácio da Liberdade & 22 & 29,3 \\
4 & Espaço do Conhecimento & 21 & 28,0 \\
5 & Memorial Minas Gerais Vale & 19 & 25,3 \\
6 & Museu Mineiro & 11 & 14,7 \\
7 & Centro Cultural Banco do Brasil & 9 & 12,0 \\
8 & Centro de Arte Popular & 6 & 8,0 \\
9 & Arquivo Público Mineiro & 4 & 5,3 \\
\hline & Total & 75 & 100,0 \\
\hline
\end{tabular}

Fonte: Elaboração pelos autores deste artigo.

Para as variáveis utilizadas na análise, foram feitos teste de médias e teste qui-quadrado (apresentados no Apêndice), de modo a verificar a diferença estatística entre o grupo de alunos que visitaram o CL com a escola e os que não o fizeram. Verifica-se que há diferenças entre os dois grupos no que tange ao interesse do aluno na escola e aos hábitos culturais formados e cultivados. Provavelmente, essa diferença decorra de um viés de seleção presente na escolha dos entrevistados, pois foram as professoras responsáveis que os designaram para a entrevista. Esse problema não teria como ser resolvido no âmbito desta pesquisa, uma vez que a unidade foi a escola e não o domicílio de residência das crianças e adolescentes. De qualquer maneira, os resultados indicam, na grande parte dos casos, ausência dessas diferenças. 
Entre os entrevistados, 84 são do sexo feminino e 70 do masculino. Ainda que a distribuição seja uniforme por gênero, observase a prevalência de alunas no conjunto dos visitantes $(62,67 \%)$ e, entre os não visitantes, a de alunos do sexo masculino (53,16\%), de acordo com o Gráfico 1. Já em relação à cor ou raça, mais da metade dos alunos (entre visitantes e não visitantes) se declaram pardos (Gráfico 2).

GRÁFICO 1 - Distribuição por sexo de não visitantes e visitantes

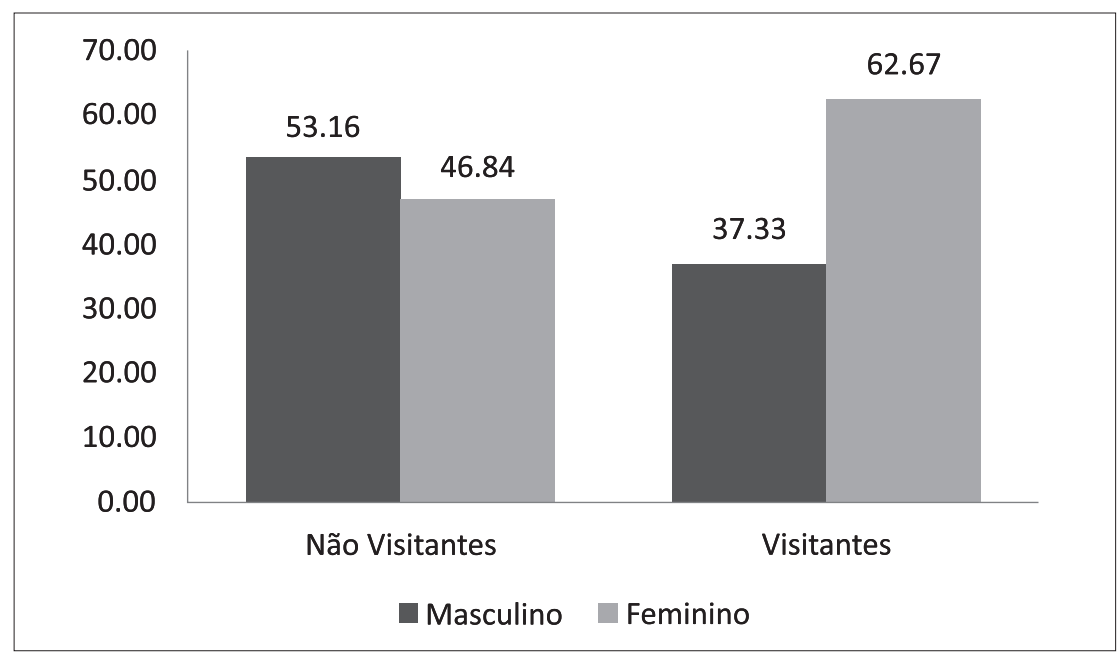

Fonte: Elaboração pelos autores deste artigo.

GRÁFICO 2 - Composição por cor entre não visitantes e visitantes

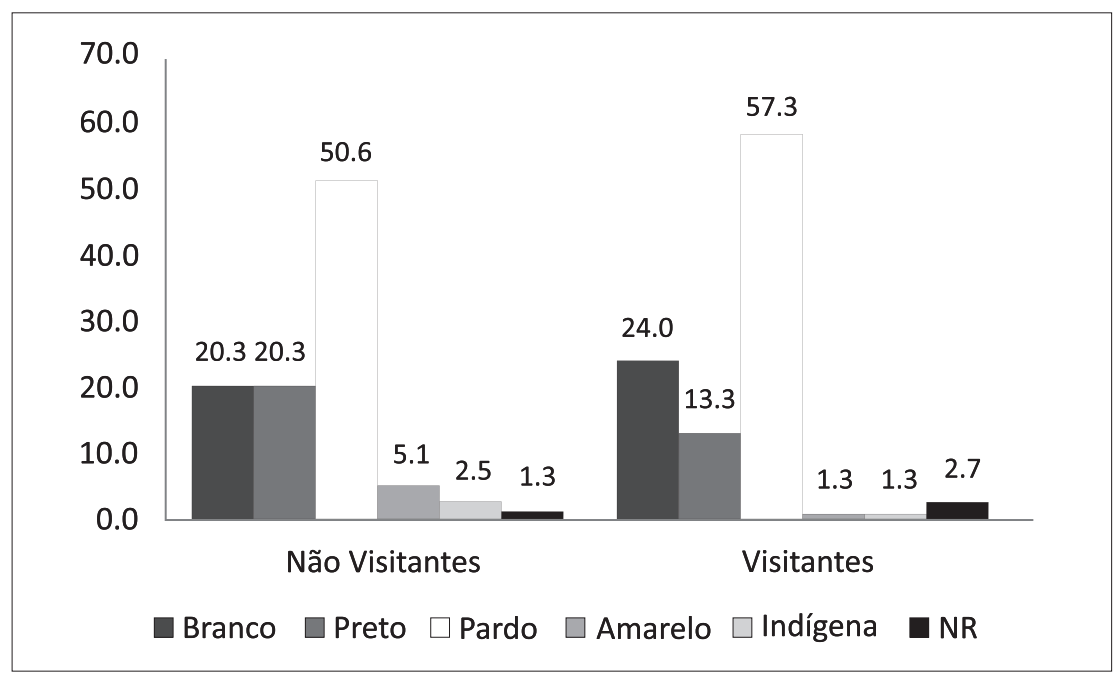

Fonte: Elaboração pelos autores deste artigo. 
Do Gráfico 3, são apreendidas as informações sobre a distribuição de alunos por idade. A média é de 15 anos, no caso de visitantes (14,78 anos) e para não visitantes (14,94 anos), mas há variação entre 13 e 18 anos. Mais de 50\% dos alunos se encontravam no $9^{\circ}$ ano, quando da visita, e cerca $16 \%$ cursavam o $8^{\circ}$ ano do Ensino Fundamental, mesmo percentual de alunos do $1^{\circ}$ ano do Ensino Médio (Gráfico 4). É possível afirmar, portanto, que temos uma amostra relativamente homogênea em termos de idade e escolaridade.

GRÁFICO 3 - Composição por idade entre não visitantes e visitantes

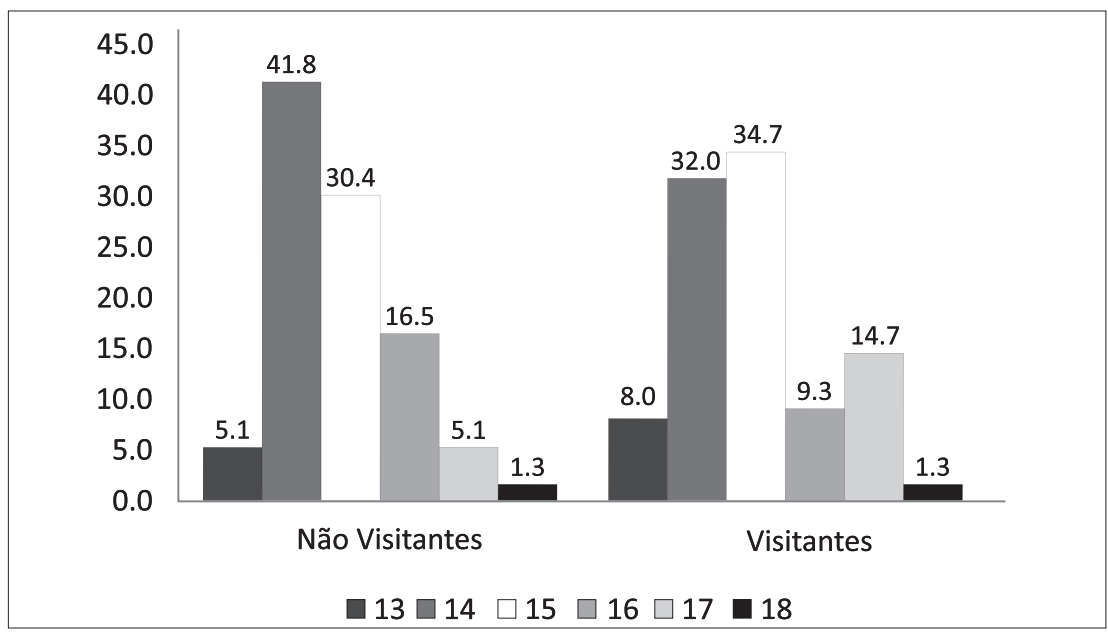

Fonte: Elaboração pelos autores deste artigo.

GRÁFICO 4 - Distribuição por série escolar entre não visitantes e visitantes

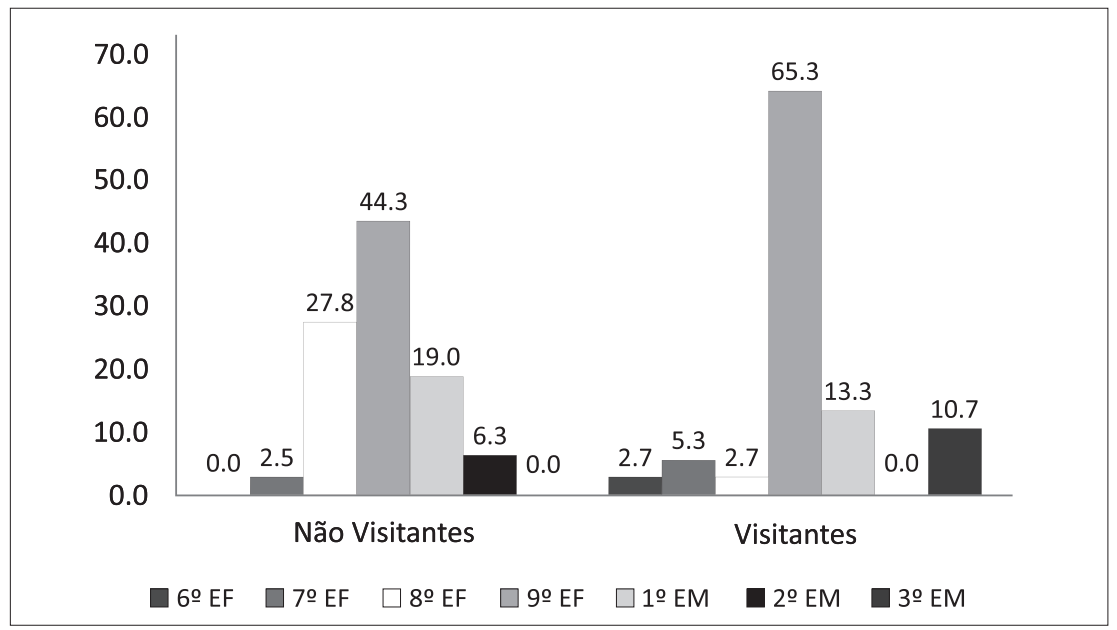

Fonte: Elaboração pelos autores deste artigo. 
Considerando-se a distribuição de ativos nos domicílios dos alunos - geladeira, computador, internet no computador, internet no celular e carro - para os dois grupos de alunos, verifica-se que a totalidade de visitantes e não visitantes possui geladeira. $\mathrm{O}$ acesso à internet também se mostrou disponível para a maior parte dos estudantes, embora, nos domicílios dos visitantes, a proporção de computador e de internet interligada seja superior se comparada à dos não visitantes. Por outro lado, nos domicílios destes últimos, o percentual dos que contam com carro é de $69,6 \%$, ao passo que, no outro grupo, é de 53,3\% (Gráfico 5).

GRÁFICO 5 - Percentual de alunos por posse de ativos, não visitantes e visitantes

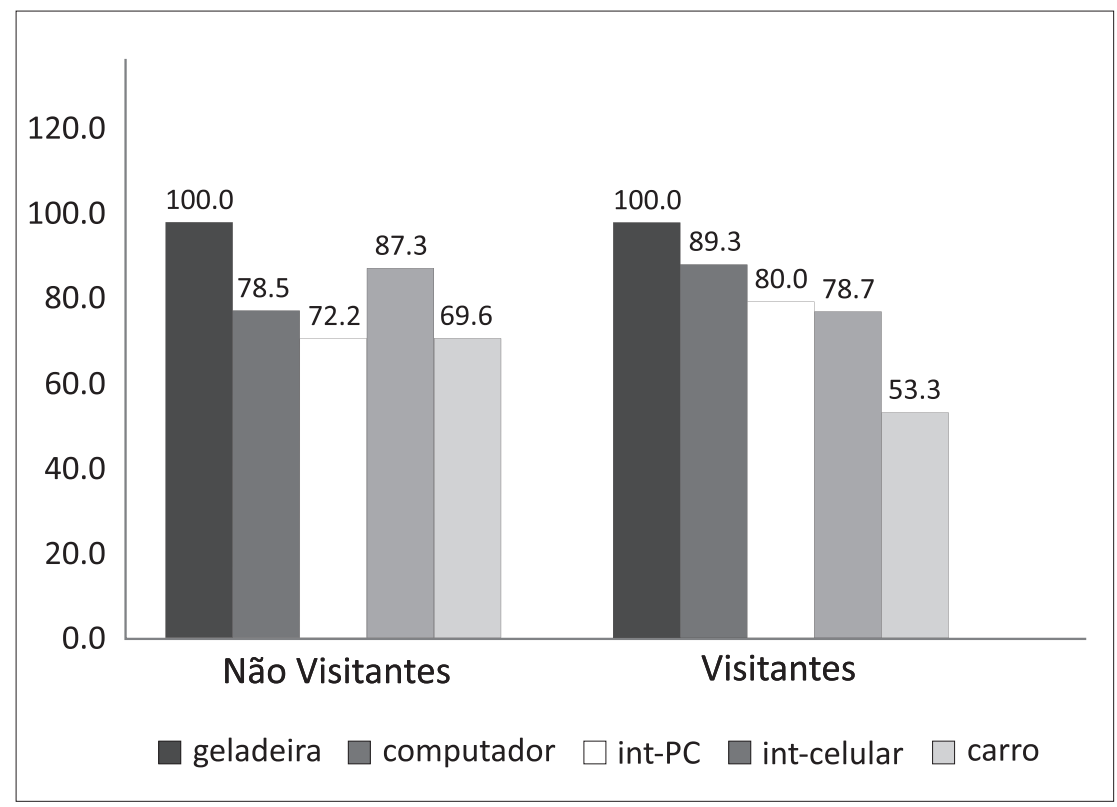

Fonte: Elaboração pelos autores deste artigo.

Ainda sobre as condições socioeconômicas dos alunos, constatou-se que $17,7 \%$ deles, na época da entrevista, trabalhavam entre os não visitantes, ao passo que $8 \%$ entre os visitantes, totalizando 20 alunos. Cerca de 19\% dos entrevistados já tinham tido alguma experiência de trabalho. Tal evidência indica precariedade dessa população, pois trata-se de jovens com idade inferior ou igual à legal para inserção no mercado de trabalho.

Quando perguntados sobre a alocação de tempo fora da escola, em ambos os grupos, visitantes e não visitantes, a maioria 
afirmou gastar seu tempo livre em redes sociais, praticando esportes, assistindo à TV, realizando tarefas domésticas, fazendo "para casa" e acessando a internet, conforme descrito no Gráfico 6.

GRÁFICO 6 - Perfil dos alunos segundo atividades fora da escola (\%)

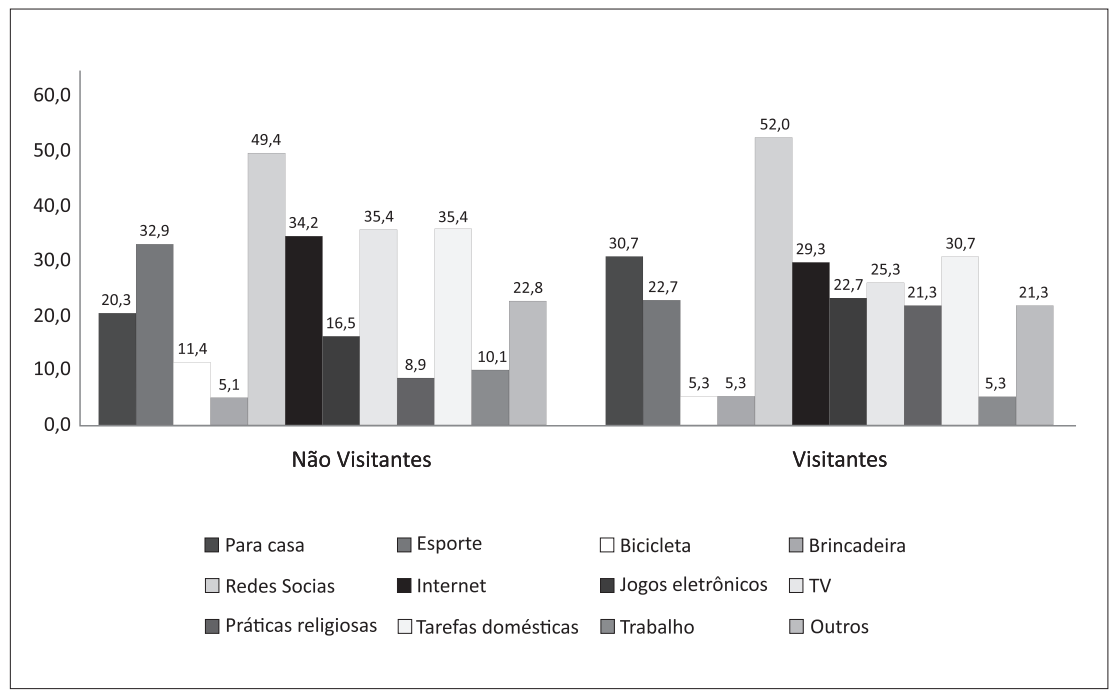

Fonte: Elaboração pelos autores deste artigo.

\section{RELAÇÃO ENTRE A VISITA E A FORMAC̣ÃO DE PÚBLICO}

No módulo referente a hábitos culturais, nota-se que 56\% dos alunos entrevistados leem livros com frequência, especialmente os visitantes (67\%). Em média, os alunos visitantes leem mais $(62 \%$ leem mais de três livros por ano) que os não visitantes (40,5\% leem mais de três livros por ano). Já a leitura de jornais é mais usual entre os alunos não visitantes e ocupa, entre os veículos, o segundo lugar em leitura (Tabela 2). A TV também é um hábito bastante comum entre os estudantes, sendo que $67 \%$ deles afirmam assistir à TV todos os dias. Como destacado na seção anterior, o acesso à internet (por computador ou por celular) é uma realidade para a maioria dos alunos, embora navegar na internet não seja identificado por muitos deles como um hábito de leitura. Cerca de 17\% desses alunos já utilizaram a internet para visitar museus virtuais. 
TABELA 2 - Número de entrevistados que tem 0 hábito de ler cada um dos seguintes veículos

\begin{tabular}{lccccccc}
\hline & Jornal & Revista & Livro & Internet & Gibi & Outros & $\begin{array}{c}\text { Total de } \\
\text { entrevistados }\end{array}$ \\
\hline $\begin{array}{l}\text { Aluno não } \\
\text { visitante }\end{array}$ & 31 & 10 & 36 & 23 & 10 & 0 & 79 \\
$\begin{array}{l}\text { Aluno visitante } \\
\text { Total }\end{array}$ & 14 & 13 & 50 & 21 & 8 & 2 & 75 \\
\hline
\end{tabular}

Fonte: Elaboração pelos autores deste artigo.

A ausência às atividades culturais fora do lar, tais como filmes em salas de cinema, peças de teatro, concertos, shows musicais e espetáculos de dança, é reportada no Gráfico 7. Quase 80\% dos alunos nunca foram a um concerto, sendo maior a parcela entre os não visitantes. Espetáculo de dança é outra atividade pouco frequentada, seguido por show.

GRÁFICO 7 - Proporção de alunos que nunca frequentou cada uma das atividades culturais

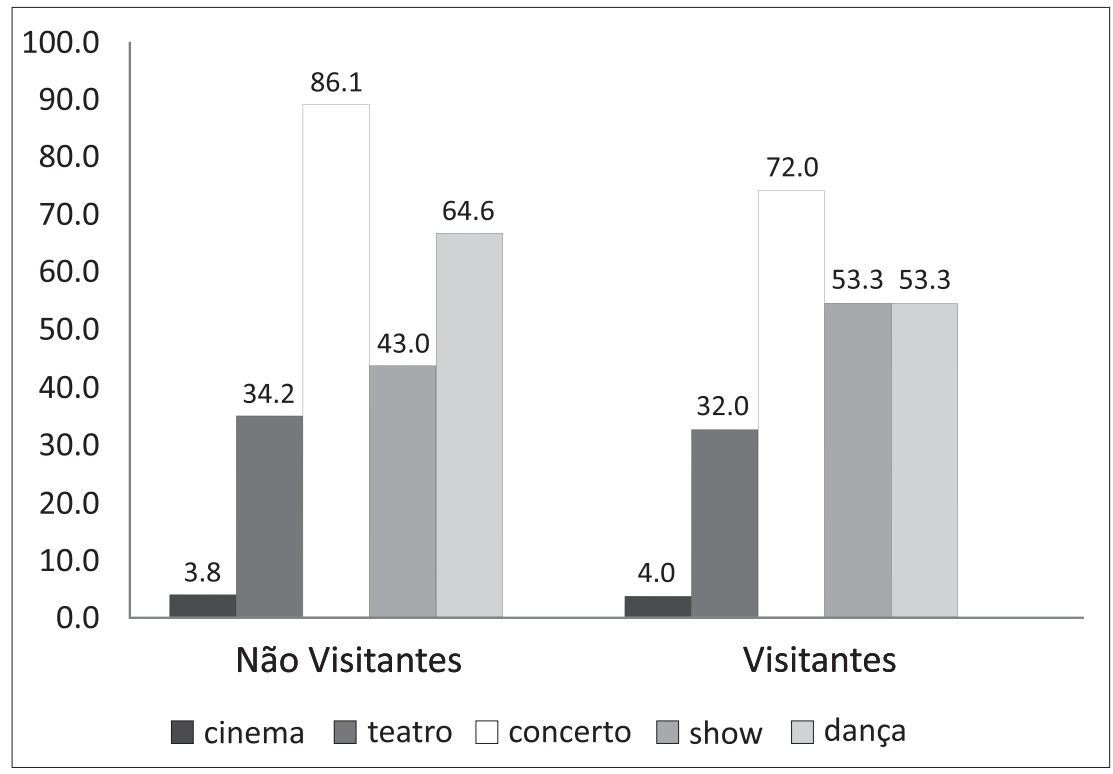

Fonte: Elaboração pelos autores deste artigo.

A assiduidade, medida pela assistência aos eventos por mais de cinco vezes ao ano, é muito baixa, com exceção de cinema. Em torno de $45 \%$ dos alunos visitantes frequentam cinema com essa 
intensidade e 36\% dos não visitantes. Para as demais atividades, a proporção é pífia, conforme registrado na Tabela 3. Quando perguntados sobre a razão da não frequência a atividades culturais, $40,5 \%$ dos não visitantes informam falta de interesse contra $30,7 \%$ dos visitantes. Para os visitantes, $42 \%$ alegam falta de responsável para acompanhá-los no evento cultural. Esses achados demonstram, ainda que de forma indireta, preferência revelada por atividades culturais para visitantes em relação a não visitantes (Gráfico 8).

TABELA 3 - Número de entrevistados que assistem frequentemente a cada um dos espetáculos culturais (mais de 5 vezes ao ano)

Cinema Teatro Concerto Show Dança Total de entrevistados

$\begin{array}{lllllll}\text { Aluno não visitante } & 29 & 1 & 1 & 5 & 3 & 79\end{array}$

$\begin{array}{lllllll}\text { Aluno visitante } & 34 & 3 & 2 & 2 & 10 & 75\end{array}$

$\begin{array}{lllllll}\text { Total } & 63 & 4 & 3 & 7 & 13 & 154\end{array}$

Fonte: Elaboração pelos autores deste artigo.

GRÁFICO 8 - Proporção de alunos segundo motivos apontados para não acesso às atividades culturais

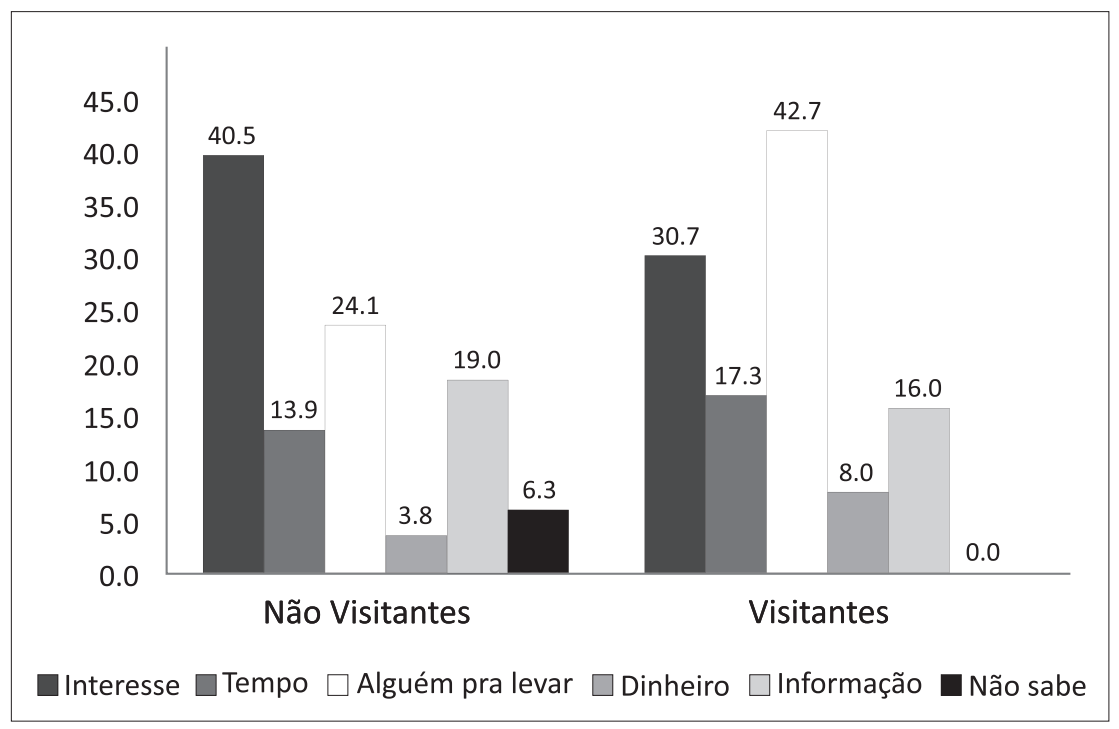

Fonte: Elaboração pelos autores deste artigo. 
Com base nas informações de hábitos culturais, foi construído um índice para cada aluno, considerando-se o número de livros lidos, frequência a cinemas, teatros, concertos, shows e espetáculos de dança, que resumisse sua frequência em um único indicador. Para tal, recorrese ao método de Análise de Componentes Principais (ACP) ${ }^{2}$. O valor médio do índice é de 0,44 para os não visitantes e 0,51 para os visitantes.

Entretanto, ao se separarem os dois grupos de alunos, segundo a escolaridade da mãe, observa-se que não há uma relação monotônica positiva entre o indicador e a escolaridade. Por exemplo, entre os alunos não visitantes, a média é maior para aqueles cuja mãe possui Ensino Fundamental Incompleto $(0,49)$ comparados aos que a mãe possui o mesmo nível finalizado $(0,38)$. No caso dos visitantes, a relação tende a ser positiva, ainda que os alunos cuja mãe tem apenas o Ensino Superior Incompleto apresentem índice de hábitos mais baixo aos de mães com escolaridade próxima (Tabela 4).

TABELA 4 - Média do Índice de Hábitos Culturais dos alunos por escolaridade da mãe Obs. Não visit. Média não visit. Obs. visit. Média visit.

\begin{tabular}{lcccc}
\hline Sem Instrução & 1 & 0,11 & 0 & - \\
Ensino Fundamental Incompleto & 17 & 0,49 & 21 & 0,48 \\
Ensino Fundamental Completo & 11 & 0,38 & 9 & 0,47 \\
Ensino Médio Incompleto & 5 & 0,49 & 8 & 0,46 \\
Ensino Médio Completo & 20 & 0,42 & 17 & 0,60 \\
Ensino Superior Incompleto & 1 & 0,68 & 2 & 0,54 \\
Ensino Superior Completo & 3 & 0,37 & 4 & 0,65 \\
Pós-Graduação & 0 & & & \\
NR* & 21 & 0,44 & 14 & 0,46 \\
\hline Total & 79 & 0,44 & 75 & 0,51 \\
\hline
\end{tabular}

Fonte: Elaboração pelos autores deste artigo. Nota: *Não respondeu ou não sabe. 
Tanto Bourdieu e Darbel (1969) quanto Stigler e Becker (1977), em suas análises sobre a formação de habitus (os primeiros) e "vício positivo" (os dois outros), destacam o papel que o histórico familiar tem sobre essa construção, uma vez que a família pode ser considerada o primeiro lugar de socialização cultural, consolidada, posteriormente, pela escola. Na população em questão, outros fatores aqui não observados parecem influenciar tal comportamento. Tais fatores podem estar relacionados, por exemplo, com a própria personalidade dos alunos, como preferências por hábitos domiciliares ou fora do domicílio, etc. Por outro lado, esse é um exercício de interpretação sobre o qual é necessário cautela, a fim de se evitar cair em uma visão simplista do gosto como uma propriedade inata. Vale frisar, por exemplo, o baixo percentual de mães que chegam a ter acesso ao Ensino Superior, como um limitante para a visualização de resultados mais robustos.

Outro achado interessante diz respeito à relação entre o índice e a informação sobre o ambiente que mais gosta na escola. Os alunos que apontaram biblioteca como lugar preferido são aqueles que detêm o mais alto indicador de hábito cultural para os dois grupos analisados (Tabela 5). Tal pergunta funciona como teste de consistência das respostas dos entrevistados e, nesse caso, a relação é adequada. Ademais, entre os visitantes, sala de aula é reconhecida como espaço preferido para alunos cuja medida de hábito ocupa o segundo lugar.

TABELA 5 - Média do Índice de Hábitos Culturais dos alunos por ambientes da escola que mais gosta

\begin{tabular}{lcccc}
\hline & Obs. Não visit. & Média não visit. & Obs. visit. & Média visit. \\
\hline Biblioteca & 13 & 0,55 & 19 & 0,59 \\
Cantina & 1 & 0,43 & 4 & 0,51 \\
Sala de aula & 8 & 0,41 & 17 & 0,51 \\
Quadra & 25 & 0,42 & 27 & 0,49 \\
Pátio & 32 & 0,42 & 15 & 0,41 \\
Outro & 1 & 0,38 & 1 & 0,31 \\
\hline
\end{tabular}

Fonte: Elaboração pelos autores deste artigo. 
É interessante notar que a maioria dos alunos possui alta identificação com a cidade de Belo Horizonte (mais de 70\% dizem gostar muito de morar na cidade) e não identifica o uso de espaços públicos como uma questão central entre as que precisam ser melhoradas na cidade. Apesar disso, cerca de $60 \%$ dos alunos não visitantes nunca tinham ouvido falar da existência do Circuito Liberdade e apenas três alunos já haviam visitado algum espaço. Já entre os que visitaram com a escola, $65 \%$ ouviram falar pela primeira vez por conta da visita e 13 alunos já haviam visitado antes de ir com a escola. Como afirma Octobre (2014, p. 158), "tornar-se visitante não pressupõe apenas vir ao museu: é preciso, ainda, voltar a ele...”. Apenas 9 dos 74 alunos que visitaram afirmam ter voltado depois ao Circuito Liberdade. Entre os que voltaram, três foram com parentes, dois com amigos, um com namorado, outro com professor de circo, outro em excursão da Cruz Vermelha e um não soube informar.

Quando informalmente questionados se os conteúdos da visita foram trabalhados em sala de aula, responderam negativamente. Ademais, muitos dos alunos tiveram dificuldade, em um primeiro momento, de recordar detalhes sobre a visita na etapa de responder ao questionário, como com qual disciplina haviam feito a visita, em que data e o nome dos espaços que visitaram. Esse aspecto, apontado pelos resultados da pesquisa, demonstra uma fragilidade na relação estabelecida entre os programas educativos dos espaços culturais e o trabalho desenvolvido em sala de aula que deveria aprofundar e relacionar os conteúdos comuns, sendo esse um dos principais desafios educativos, culturais e pedagógicos do que Habib e Mengin (2014) denominam de "saídas culturais" escolares, sobretudo, em um contexto em que a contribuição da escola tende a ser mais significativa que a familiar.

Os achados, portanto, deste projeto piloto sugerem que as ações educativas desenvolvidas nesse ambiente cultural não contribuíram para despertar o interesse desses alunos como público desses espaços culturais. Muitas podem ser as razões, o que aponta para uma necessidade de aprofundamento do objeto de estudo: falta de trabalho pedagógico com ênfase nessa formação; dificuldades de mobilidade e acesso, pois são menores e dependem de adultos para visitar; distância das residências ao CL; alguns trabalham; horário de funcionamento; entre outros. 


\section{CONSIDERAÇÕES FINAIS}

Ressaltamos que, nos últimos anos, temos deparado com resultados de pesquisas específicas sobre o público de atividades culturais e os hábitos da população, o que significa a existência de dados disponíveis que possam contribuir para o planejamento de políticas públicas para os espaços culturais (museus, centros culturais, bibliotecas e outros) e sua relação com o campo educacional.

As ações educativas em museus que, como bem lembram Cazelli e Franco (2006), integram a formação de práticas culturais em jovens que, muitas vezes, não contam com o histórico familiar e que, por isso, seus hábitos precisam ser cultivados por instituições para que a desigualdade presente também no acesso à cultura, em sua descrição mais ampla, seja minimizada. Para esses autores:

\footnotetext{
Os espaços de cultura com todas as suas potencialidades, principalmente para os jovens, são momentos privilegiados de construção de relacionamentos sociais com múltiplas mediações, desde os mais orientados para a satisfação de necessidades pessoais até aqueles voltados para o estabelecimento de vínculos sociais. (CAZELLI; FRANCO, 2006, p. 16-17)
}

É importante destacar, ainda, os limites da análise quantitativa nesses casos, incapaz de captar a contento a diversidade das experiências estéticas e cognitivas vividas por cada um dos alunos que visitaram os espaços. Some-se a isso a dificuldade de definir o que se trata como cultura. No contexto da pesquisa reportada neste trabalho, ainda prevalece a definição de uma prática cultural atrelada a um perfil de consumidor europeu. Para além dessas atividades, há que se considerar outras manifestações que ocorrem como samba de roda, capoeira, quadrilhas, entre outros.

Tais limites, entretanto, não se resolvem simplesmente pela inclusão de perguntas abertas no questionário, mas talvez dependam mais de outras abordagens como entrevistas em profundidade ou grupos focais, especialmente quando se trata de um público jovem que pode ter mais dificuldade em responder a um modelo mais formal de questionário. No entanto, é preciso criar a possibilidade de desenvolvimento de pesquisas contínuas, permitindo futuras análises comparativas e acompanhamento dos programas culturais e educacionais desses espaços.

Diante dos resultados apontados, reiteramos que o posicionamento dos sujeitos no campo cultural depende, em grande parte, da situação onde se encontram no contexto sociocultural e econômico, em que o diferencial está no acúmulo de capital cultural que, 
inicialmente, vem do próprio meio familiar, da educação e da convivência social. No contexto das periferias dos grandes centros urbanos, os movimentos sociais e comunitários tornaram-se um espaço privilegiado de aprendizagem coletiva e de oferta de atividades culturais, o que deve ser considerado como objeto de pesquisa em futuras abordagens.

O papel dos próprios equipamentos como agentes dessa socialização também é um aspecto fundamental que precisa ser melhor analisado. Embora muitos museus venham buscando abrir espaço para uma estética de caráter mais popular, a forma como o fazem (restringindo-se ao popular já legitimado como "arte" e expondo-o de modo a valorizar esse aspecto) parece não ser suficiente para ampliar a abertura a um público também popular (JANCHERY; PRAET, 2014).

\section{REFERÊNCIAS}

BENHAMOU, F. A economia da cultura. São Paulo: Ateliê Editorial, 2007.

BOURDIEU, P. ; DARBEL, P. L' amour de l'art: lês musées d' art européen et leur public. Paris: Ed. De Minuit, 1969.

CAZELLI, S.; FRANCO, C. Os diferentes tipos de capital mobilizados no contexto escolar e o acesso dos jovens a museus, 2006. Disponível em: < http://www.anped.org. br/sites/default/files/gt14-1789-int.pdf>. Acesso em: 30 ago. 2016.

CPIM. DEPMUS. IBRAM. O “não público” dos museus: levantamento estatístico sobre o "não ir" a museus no Distrito Federal. Brasília: CPIM; DEPMUS; IBRAM, 2012. 20p. Relatório Final da Pesquisa.

EIDELMAN, J.; ROUSTAN, M. Os estudos sobre público: pesquisa fundamental, escolhas de políticas e apostas operacionais. In: EIDELMAN, J.; ROUSTAN, M.; GOLDSTEIN, B. (Org.). O lugar do público: sobre o uso de estudos e pesquisas pelos museus. São Paulo: Iluminuras: Itaú Cultural, 2014, p. 13-40.

HABIB, M.; MENGIN, A. Evolução das expectativas do público e capitalização dos estudos para as futuras exposições da CitédesSciences e de l'Industrie. In: EIDELMAN, J.; ROUSTAN, M.; GOLDSTEIN, B. (Org.). O lugar do público: sobre o uso de estudos e pesquisas pelos museus. São Paulo: Iluminuras: Itaú Cultural, 2014, p. 161-176.

INSTITUTO BRASILEIRO DE GEOGRAFIA E ESTATÍSTICA - IBGE. Pesquisa domiciliar sobre percepção e visita a museus 2008. Rio de Janeiro: IBGE, 2008. 20p. Relatório de Pesquisa Número 22.

JANCHERY, A.; PRAET, M. van. Ir com a família aos museus: otimizar as negociações. In: EIDELMAN, J.; ROUSTAN, M.; GOLDSTEIN, B. (Org.). O lugar do público: sobre o uso de estudos e pesquisas pelos museus. São Paulo: Iluminuras: Itaú Cultural, 2014, p. 161-176.

KÖPTCKE, L. S.; CAZELLI, S.; LIMA, J. M. de. Museus e seus visitantes: relatório de pesquisa perfil-opinião 2005. Brasília: Observatório de Museus e Centros Culturais Fundação Oswaldo Cruz; Rio de Janeiro: IPHAN, 2008. 76p. Relatório.

KÖPTCKE, L. S. Público, o X da questão? A construção de uma agenda de pesquisa sobre os estudos de público no Brasil. Museologia \& Interdisciplinaridade, Brasília, v. 1, n. 1, p.209-235, jan./jul. 2012. (Revista do Programa de Pós-Graduação em Ciência da 
Informação da Universidade de Brasília).

KÖPTCKE, L. S. (Coord.). Pesquisa perfil-opinião 2006/2007: análise descritiva preliminar dos dados agregados dos museus participantes da pesquisa em São Paulo. São Paulo: Observatório de Museus e Centros Culturais, 2008. 44p.

NASCIMENTO, S. S. A relação museu e escola: um duplo olhar sobre a ação educativa em seis museus de Minas Gerais. Ensino em Re-Vista (On-line), Uberlândia, v. 20, n. 1, p. 179-192, jan./jun. 2013.

OCTOBRE, S. Introdução (Parte III). In: EIDELMAN, J.; ROUSTAN, M.; GOLDSTEIN, B. (Org.). O lugar do público: sobre o uso de estudos e pesquisas pelos museus. São Paulo: Iluminuras: Itaú Cultural, 2014, p. 155-160.

STIGLER, G. J.; BECKER, G. S. De gustibus non estdisputandum. American Economic Review, Nashville, 67(2), p. 76-90, mar. 1977.

YÚDICE, G. A conveniência da cultura: usos da cultura na era global. Belo Horizonte: Editora UFMG, 2006. 615 p.

\section{NOTAS}

${ }^{1}$ Disponívelem: < https://www.flickr.com/photos/portalpbh/sets/72157638355730985/>. Acesso em: 4 maio 2015.

${ }^{2}$ A explicação do cálculo do índice encontra-se no Apêndice A.

Submetido: 02/06/2015

Aprovado: 16/09/2015

Contato:

Av Antônio Carlos, 6627

Prédio Face, Sala 3040

Belo Horizonte |MG |Brasil

CEP 31.270-901 
APÊNDICE A - TESTE DE DIFERENÇAS (QUI-QUADRADO)

\begin{tabular}{|c|c|c|c|c|}
\hline $\begin{array}{l}\text { Gráfico ou } \\
\text { Tabela }\end{array}$ & Variável & $\begin{array}{c}\text { Estatística } \\
\qquad \mathrm{X}^{2}\end{array}$ & p (módulo) & $\begin{array}{l}\text { Diferença entre } \\
\text { visitantes e não } \\
\text { visitantes }\end{array}$ \\
\hline Gráfico 1 & Sexo & 3.8892 & 0.049 & SIM, a $5 \%$ \\
\hline Gráfico 2 & Cor & 3.9761 & 0.553 & NÃO \\
\hline Gráfico 3 & Idade & 6.8685 & 0.231 & NÃO \\
\hline Gráfico 4 & Série & 35.5868 & 0.000 & SIM, a $1 \%$ \\
\hline Gráfico 5 & Computador & 3.3322 & 0.068 & SIM, a $10 \%$ \\
\hline Gráfico 5 & Internet-pc & 8.3501 & 0.015 & SIM, a $5 \%$ \\
\hline Gráfico 5 & Int-celular & 2.4384 & 0.295 & NÃO \\
\hline Gráfico 5 & Carro & 4.9920 & 0.082 & SIM, a $10 \%$ \\
\hline Gráfico 6 & Para casa & 2.2062 & 0.137 & NÃO \\
\hline Gráfico 6 & Esporte & 2.0064 & 0.157 & NÃO \\
\hline Gráfico 6 & Bicicleta & 1.8275 & 0.176 & NÃO \\
\hline Gráfico 6 & Brincadeira & 0.0057 & 0.940 & NÃO \\
\hline Gráfico 6 & Redes sociais & 0.1067 & 0.744 & NÃO \\
\hline Gráfico 6 & Internet & 0.4161 & 0.519 & NÃO \\
\hline Gráfico 6 & $\begin{array}{l}\text { Jogos } \\
\text { eletrônicos }\end{array}$ & 0.9462 & 0.331 & NÃO \\
\hline Gráfico 6 & $\mathrm{TV}$ & 1.8544 & 0.173 & NÃO \\
\hline Gráfico 6 & $\begin{array}{l}\text { Práticas } \\
\text { religiosas }\end{array}$ & 4.7111 & 0.030 & SIM, a $5 \%$ \\
\hline Gráfico 6 & $\begin{array}{l}\text { Tarefas } \\
\text { domésticas }\end{array}$ & 0.3963 & 0.529 & NÃO \\
\hline
\end{tabular}




\begin{tabular}{|c|c|c|c|c|}
\hline Gráfico 6 & Trabalho & 1.2303 & 0.267 & NÃO \\
\hline Gráfico 6 & Outros & 0.0471 & 0.828 & NÃO \\
\hline Tabela 2 & Jornal & 7.8741 & 0.005 & SIM, a $1 \%$ \\
\hline Tabela 2 & Revista & 0.6619 & 0.416 & NÃO \\
\hline Tabela 2 & Livro & 6.9446 & 0.008 & SIM, a $1 \%$ \\
\hline Tabela 2 & Internet & 0.0234 & 0.878 & NÃO \\
\hline Tabela 2 & Gibi & 0.1478 & 0.701 & NÃO \\
\hline Tabela 2 & Outros & 2.1344 & 0.144 & NÃO \\
\hline $\begin{array}{l}\text { Gráfico } 7 \\
\text { e Tabela } 3\end{array}$ & Cinema & 1.4417 & 0.696 & NÃO \\
\hline $\begin{array}{l}\text { Gráfico } 7 \\
\text { e Tabela } 3\end{array}$ & Teatro & 2.6944 & 0.441 & NÃO \\
\hline $\begin{array}{l}\text { Gráfico } 7 \\
\text { e Tabela } 3\end{array}$ & Concerto & 6.5287 & 0.089 & SIM, a $10 \%$ \\
\hline $\begin{array}{l}\text { Gráfico } 7 \\
\text { e Tabela } 3\end{array}$ & Show & 3.6952 & 0.296 & NÃO \\
\hline $\begin{array}{l}\text { Gráfico } 7 \\
\text { e Tabela } 3\end{array}$ & Dança & 4.9984 & 0.172 & NÃO \\
\hline Gráfico 8 & Interesse & 1.6225 & 0.203 & NÃO \\
\hline Gráfico 8 & Tempo & 0.3399 & 0.560 & NÃO \\
\hline Gráfico 8 & $\begin{array}{l}\text { Alguém para } \\
\text { levar }\end{array}$ & 6.0197 & 0.014 & SIM, a $5 \%$ \\
\hline Gráfico 8 & Dinheiro & 1.2349 & 0.266 & NÃO \\
\hline Gráfico 8 & Informação & 0.2375 & 0.626 & NÃO \\
\hline Gráfico 8 & Não sabe & 4.9061 & 0.027 & SIM, a $5 \%$ \\
\hline Tabela 4 & $\begin{array}{l}\text { Escolaridade } \\
\text { mãe }\end{array}$ & 4.3318 & 0.741 & $\mathrm{O}$ \\
\hline
\end{tabular}




\begin{tabular}{clccc} 
Tabela 5 & Biblioteca & 1.8420 & 0.175 & NÃO \\
Tabela 5 & Cantina & 2.0263 & 0.155 & NÃO \\
Tabela 5 & Sala de aula & 4.4492 & 0.035 & SIM, a 5\% \\
Tabela 5 & Quadra & 0.3262 & 0.568 & NÃO \\
Tabela 5 & Pátio & 7.6296 & 0.006 & SIM, a 1\% \\
Tabela 5 & Outro & 0.0014 & 0.970 & NÃO \\
\hline
\end{tabular}

Teste de médias não paramétrico (Mann-Whitney)

\begin{tabular}{lllll}
$\begin{array}{l}\text { Gráfico ou } \\
\text { Tabela }\end{array}$ & Variável & Estatística t & p (módulo) & $\begin{array}{l}\text { Diferença entre } \\
\text { visitantes e não visitantes }\end{array}$ \\
\hline Tabela 4 & IHC & -2.162 & 0.0306 & SIM, a $5 \%$ \\
\hline
\end{tabular}

Análise de componentes principais - Índice de Hábitos Culturais

Número de observações: 154 (alunos, visitantes e não visitantes)

Número de Componentes: 6

\begin{tabular}{rrrrr}
\hline Componente & Autovalor & Diferença & $\%$ & Cumulativo \\
\hline 1 & 1,75461 & 0,670738 & 0,2924 & 0,2924 \\
2 & 1,08387 & 0,0808673 & 0,1806 & 0,4731 \\
3 & 1,00301 & 0,14733 & 0,1672 & 0,6402 \\
4 & 0,855676 & 0,0889064 & 0,1426 & 0,7829 \\
5 & 0,766769 & 0,230704 & 0,1278 & 0,9107 \\
6 & 0,536065 & & 0,0893 & 1,0000 \\
\hline
\end{tabular}




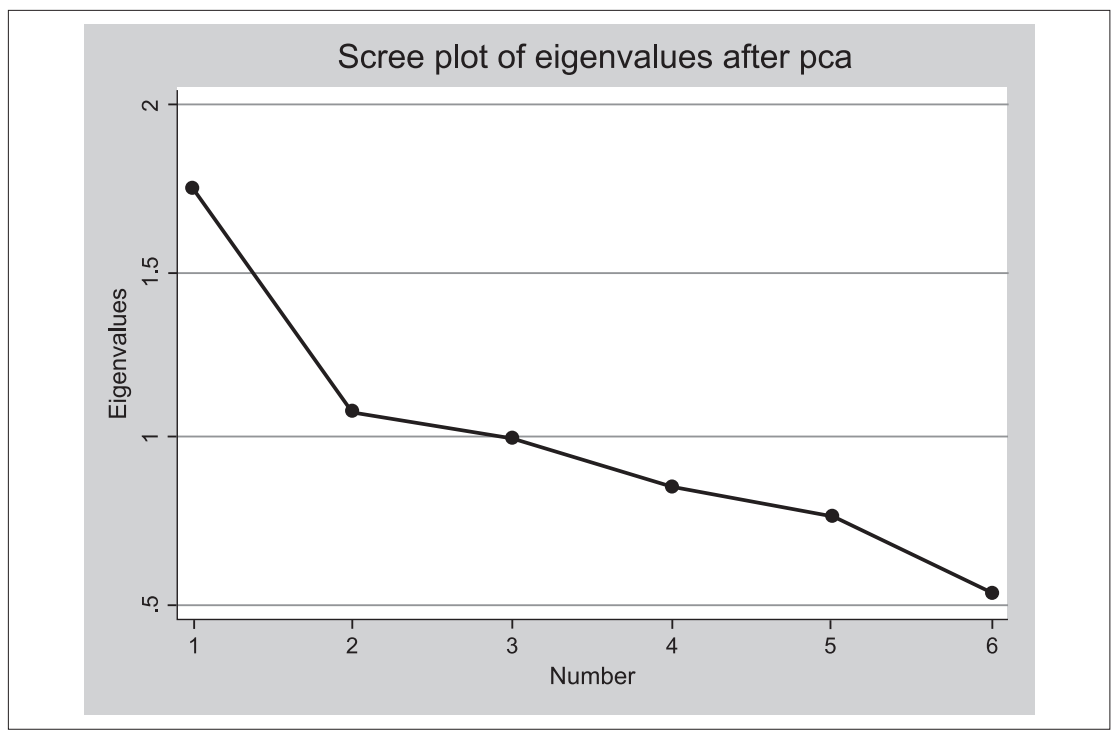

De acordo com o estudo dos autovalores e dos percentuais de explicação, consideramos os 3 primeiros componentes para a construção do Índice de Hábitos Culturais (IHC), que somados explicam $64 \%$ da variação da amostra, cujos autovetores se expressam a seguir:

\begin{tabular}{rrrr}
\hline Variável & Comp1 & Comp2 & Comp3 \\
\hline n. livros & 0,4860 & 0,4638 & $-0,1713$ \\
cinema & 0,5393 & $-0,2612$ & $-0,1436$ \\
teatro & 0,3044 & $-0,2941$ & 0,6819 \\
concerto & 0,4288 & 0,1068 & $-0,4530$ \\
show & 0,3447 & $-0,5626$ & $-0,0002$ \\
dança & 0,2786 & 0,5497 & 0,5290 \\
\hline
\end{tabular}

Cada componente representa uma dimensão no índice, de tal maneira que:

$\operatorname{dim} 1=0,4860 *$ cinema $+0,5393 *$ teatro $+0,3044 *$ concerto $+0,4288 *$ show + $0,3447 *$ dança $+0,2786 *$ n_livros

$\operatorname{dim} 2=0,4638 *$ cinema $-0,2612 *$ teatro $-0,2941 *$ concerto $+0,1068 *$ show $0,5626 *$ dança $+0,5497 *$ n_livros

$\operatorname{dim} 3=-0,1713 *$ cinema $-0,1436 *$ teatro $+0,6819 *$ concerto $-0,4530 *$ show $0.0002 *$ dança $+0,5290 * n_{-}$livros

$\mathrm{IHC}=1,75461 * \operatorname{dim} 1+1,08387 * \operatorname{dim} 2+1,00301 * \operatorname{dim} 3$

Onde o peso de cada dimensão é dado pelo autovalor de cada componente.

E IHC_N representa o IHC normalizado (variação entre 0 e 1) 


\section{ANEXO A - QUESTIONÁRIO ALUNOS DE ESCOLA PÚBLICA (VISITANTES)}

Qual sua idade? anos completos

Em que ano você estuda?

[ ] $9^{\circ}$ ano Ensino Fundamental

[ ] $1^{\circ}$ ano Ensino Médio [ ] $2^{\circ}$ ano Ensino Médio [ ] $3^{\circ}$ ano Ensino Médio

Parte 1: Condições individuais e familiares

1. Sexo:[ ] Masculino [ ] Feminino

2. Qual o bairro onde mora?

3. Em relação à sua cor ou raça, você se considera:

[ ] Branco [ ] Preto [ ] Amarelo [ ] Pardo [ ] Indígena

4. Contando com você, quantas pessoas moram na sua casa?

5. Quantos irmãos moram com você?

6. Além de irmãos, quem mora com você?

[ ] Mãe [ ] Pai [ ] Avó [ ]Avô [ ] Tio [ ] Cunhado.

[ ] Outro:

7. Qual (is) é (são) a(s) disciplina(s) que você mais gosta?

[ ] Português [ ] Matemática [ ] Ciências [ ] Física [ ] Química

[ ] Biologia [ ] História [ ] Geografia [ ] Educação Física

[ ] Outras:

8. Qual (is) disciplina (s) você menos gosta? [ ]Português [ ]Matemática

[ ] Ciências [ ] Física [ ] Química [ ] Biologia [ ] História

[ ] Geografia [ ] Educação Física

[ ] Outras:

9. Qual o lugar da escola que você mais gosta?

[ ] Biblioteca [ ] Cantina [ ] Sala de aula [ ] Quadra [ ] Pátio

[ ] Outros:

10. Qual o lugar da escola que você menos gosta?

[ ] Biblioteca [ ] Cantina [ ] Sala de aula [ ] Quadra [ ] Pátio

[ ] Outros:

11. Você trabalha atualmente?[ ] Sim (Pule para a 11.2) [ ] Não

11.1 Você já trabalhou? [ ] Sim [ ] Não (Pule para a 12)

11.2 Com que idade começou a trabalhar? anos.

12. Qual a escolaridade da sua mãe?

[ ] Sem instrução [ ] Ens. Fundamental Incompleto

[ ] Ens. Fundamental Completo

[ ] Ensino Médio Incompleto [ ] Ens. Médio Completo

[ ] Ens. Superior Incompleto

[ ] Ens. Superior Completo [ ] Não sabe 
13. Você tem geladeira em sua casa? [ ] Sim ～[ ] Não (pule para a 14) 13.1 Quantas?

14. Você tem computador? [ ] Sim [ ] Não (pule para a 15) 14.1 Quantos?

15. Você tem acesso à internet em sua casa? [ ]Sim [ ]Não (pule para a 16) 15.1 Você acessa pelo: [ ] Computador [ ] Celular

16. A sua família tem carro? [ ] Sim [ ] Não (pule para a 17) 16.1 Quantos?

\section{Parte 2: Hábitos}

17. Qual profissão você quer ter?

18. O que você costuma ler?

[ ] Jornal [ ] Revista [ ] Livro [ ] Conteúdo pela internet

[ ] Livros [ ] Gibi/Revistinha

[ ] Outros:

19. Aproximadamente quantos livros de literatura você leu no último ano? [ ] 0 [ ] 1 a 3 [ ] 3 a 5 [ ] 5 a 10 [ ] Mais que 10

20. Com que frequência você assiste à TV ?

[ ] Todos os dias [ ] Algumas vezes por semana

[ ] Algumas vezes por mês [ ] Raramente [ ] Nunca

21. Qual é seu livro favorito? [ ] Não tem.

22. Qual é seu filme favorito? [ ] Não tem.

23. Com que frequência você vai à(ao):

\begin{tabular}{|l|l|l|l|l|}
\hline \multicolumn{1}{|c|}{ Atividade } & Nunca foi & $\begin{array}{c}\text { Raramente } \\
\text { (1 vez ao ano } \\
\text { ou menos) }\end{array}$ & $\begin{array}{c}\text { Às vezes } \\
\text { (2 a 5 vezes ao } \\
\text { ano) }\end{array}$ & $\begin{array}{c}\text { Frequentemente } \\
\text { (mais de 5 vezes } \\
\text { ao ano) }\end{array}$ \\
\hline Cinema & & & & \\
\hline Teatro & & & & \\
\hline Concerto & & & & \\
\hline Show & & & & \\
\hline Dança & & & & \\
\hline
\end{tabular}

23.1 Para você, qual o principal motivo para não frequentar essas atividades:

[ ] falta de interesse [ ] falta de tempo [ ] falta de alguém que possa levá-lo [ ] falta de dinheiro [ ] falta de informação sobre a existência dos espetáculos [ ] não sabe a razão

24. Você já visitou algum museu virtual (museu na internet) ?[ ]Sim [ ]Não

25. O que você mais faz no seu tempo livre (fora da escola)? 
[ ] elabora o para casa [ ] pratica algum esporte [ ] anda de bicicleta

[ ] brinca [ ] usa redes sociais (Facebook, Twitter, Instagram, WhatsApp)

[ ] navega na internet [ ] usa jogos eletrônicos [ ] assiste à TV

[ ] participa de práticas religiosas [ ] ajuda em tarefas domésticas

[ ] trabalha [ ] outros:

\section{Você gosta de morar em Belo Horizonte?}

[ ] Não gosto [ ] Sou indiferente [ ] Gosto pouco [ ] Gosto muito 26.1 Por quê?

27. Você participa de alguma associação (EXPLICAR) em sua comunidade?

[ ] Sim [ ] Não (pule para a 28)

27.1 Qual?

28. Considerando as melhorias necessárias em sua cidade, ordene de $\mathbf{1}$ a 5 , de acordo com a importância dos aspectos que mais precisam melhorar?

[ ] Limpeza urbana

[ ] Transporte público

[ ] Saúde

[ ] Uso de praças, parques, museus, centros culturais, centros esportivos, etc.

[ ] Educação

\section{Parte 3: Sobre o CL}

29. Com qual disciplina você visitou o Circuito Liberdade?

30. Quando você visitou o Circuito Liberdade?

Dia:__ [ ] Não sei / Mês:___ [ ] Não sei / Ano:___ [ ] Não sei

31. Quais espaços/equipamentos você visitou e qual a sua opinião sobre eles?

\begin{tabular}{|l|l|l|l|l|l|l|}
\hline Espaço visitado hoje & Ótimo & Bom & Regular & Ruim & Péssimo & Não sei \\
\hline 1- Arquivo Público Mineiro [ ] & & & & & & \\
\hline $\begin{array}{l}\text { 2- Biblioteca Pública Estadual } \\
\text { Luiz de Bessa [ ] }\end{array}$ & & & & & & \\
\hline 3- Centro de Arte Popular - Cemig [ ] & & & & & & \\
\hline 4- Centro Cultural Banco do Brasil [ ] & & & & & & \\
\hline 5- Espaço do Conhecimento UFMG [ ] & & & & & & \\
\hline 6- Memorial Minas Gerais Vale [ ] & & & & & & \\
\hline 7- Museu das Minas e do Metal [ ] & & & & & & \\
\hline 8- Museu Mineiro [ ] & & & & & & \\
\hline 9- Palácio da Liberdade [ ] & & & & & & \\
\hline 10- Praça da Liberdade [ ] & & & & & & \\
\hline $\begin{array}{l}\text { 11- Horizonte Sebrae - } \\
\text { Casa da Economia Criativa [ ] }\end{array}$ & & & & & & \\
\hline
\end{tabular}


32. Qual era a sua idade na época da visita?

33. Em que ano você estava na escola?

34. Antes da visita, você já tinha ouvido falar do CL?

[ ] Sim [ ] Não (pule para a 35)

34.1 Como você ficou sabendo a respeito do Circuito Liberdade?

[ ] Passando em frente ao circuito

[ ] Visitando outros museus ou circuitos culturais

[ ] Na televisão [ ] No rádio

[ ] Através de panfletos, cartazes, outdoors

[ ] Lendo jornais ou revistas [ ] No guia turístico

[ ] Por recomendação de amigos [ ] Por recomendação de professores

[ ] Por recomendação de familiares [ ] Pela sinalização de rua

[ ] Na internet

[ ] Outra fonte. Qual?

35. Antes da visita com a escola, você já tinha visitado o Circuito

Liberdade?

[ ] Sim [ ] Não (pule para a 36)

35.1 Com quem você o visitou?

[ ] Parentes 35.1.1 Qual(is)?

[ ] Outra escola

[ ] Amigos

[ ] Outros:

36. Você voltou depois da visita com a escola?

[ ] Sim [ ] Não (pule para a 37)

36.1 Com quem você voltou?

[ ] Parentes 36.1.1 Qual(is)?

[ ] Escola

[ ] Amigos

[ ] Outros:

37. A visita te marcou em algo?

38. De que você mais se lembra na visita?

39. Você gostou de ter vindo com a escola?[ ]Sim [ ]Não 39.1 Por quê?

Obrigada(o)! 
ANEXO B - QUESTIONÁRIO ALUNOS DE ESCOLA PÚBLICA (NÃO VISITANTES)

Qual sua idade? anos completos

Em que ano você estuda?

[ ] $9^{\circ}$ ano Ensino Fundamental

[ ] $1^{\circ}$ ano Ensino Médio [ ] $2^{\circ}$ ano Ensino Médio [ $] 3^{\circ}$ ano Ensino Médio

Parte 1: Condições individuais e familiares

1. Sexo:[ ] Masculino [ ] Feminino

2. Qual o bairro onde mora?

3. Em relação à sua cor ou raça, você se considera:

[ ] Branco [ ] Preto [ ] Amarelo [ ] Pardo [ ] Indígena

4. Contando com você, quantas pessoas moram na sua casa?

5. Quantos irmãos moram com você?

6. Além de irmãos, quem mora com você?

[ ] Mãe [ ] Pai [ ]Avó [ ]Avô [ ] Tio [ ] Cunhado.

[ ] Ouro:

7. Qual (is) é (são) a(s) disciplina(s) que você mais gosta?

[ ] Português [ ] Matemática [ ] Ciências [ ] Física [ ] Química

[ ] Biologia [ ] História [ ] Geografia [ ] Educação Física

[ ] Outras:

8. Qual (is) disciplina (s) você menos gosta?

[ ] Português [ ] Matemática [ ] Ciências [ ] Física [ ] Química

[ ] Biologia [ ] História [ ] Geografia [ ] Educação Física

[ ] Outras:

9. Qual o lugar da escola que você mais gosta?

[ ] Biblioteca [ ] Cantina [ ] Sala de aula [ ] Quadra [ ] Pátio

[ ] Outros:

10. Qual o lugar da escola que você menos gosta?

[ ] Biblioteca [ ] Cantina [ ] Sala de aula [ ] Quadra [ ] Pátio

[ ] Outros:

11. Você trabalha atualmente?[ ] Sim (Pule para a 11.2) [ ] Não

11.1 Você já trabalhou? [ ] Sim [ ] Não (Pule para a 12)

11.2 Com que idade começou a trabalhar? anos.

12. Qual a escolaridade da sua mãe?

[ ] Sem instrução [ ] Ens. Fundamental Incompleto

[ ] Ens. Fundamental Completo

[ ] Ensino Médio Incompleto [ ] Ens. Médio Completo

[ ] Ens. Superior Incompleto

[ ] Ens. Superior Completo [ ] Não sabe 
13. Você tem geladeira em sua casa? [ ] Sim ～[ ] Não (pule para a 14) 13.1 Quantas?

14. Você tem computador? [ ] Sim [ ] Não (pule para a 15) 14.1 Quantos?

15. Você tem acesso à internet em sua casa? [ ] Sim [ ] Não (pule para a 16) 15.1 Você acessa pelo: [ ] Computador [ ] Celular

16. A sua família tem carro? [ ] Sim [ ] Não (pule para a 17) 16.1 Quantos?

\section{Parte 2: Hábitos}

17. Qual profissão você quer ter?

18. O que você costuma ler?

[ ] Jornal [ ] Revista [ ] Livro [ ] Conteúdo pela internet

[ ] Livros [ ] Gibi/Revistinha

[ ] Outros:

19. Aproximadamente quantos livros de literatura você leu no último ano? [ ] 0 [ ] 1 a 3 [ ] 3 a 5 [ ] 5 a 10 [ ] Mais que 10

20. Com que frequência você assiste à TV ?

[ ] Todos os dias [ ] Algumas vezes por semana

[ ] Algumas vezes por mês [ ] Raramente [ ] Nunca

21. Qual é seu livro favorito? [ ] Não tem.

22. Qual é seu filme favorito? [ ] Não tem.

23. Com que frequência você vai à (ao):

\begin{tabular}{|l|l|c|c|c|}
\hline Espetáculo & Nunca foi & $\begin{array}{c}\text { Raramente } \\
\text { (1 vez ao ano } \\
\text { ou menos) }\end{array}$ & $\begin{array}{c}\text { Às vezes } \\
\text { (2 a 5 vezes ao } \\
\text { ano) }\end{array}$ & $\begin{array}{c}\text { Frequentemente } \\
\text { (mais de 5 vezes } \\
\text { ao ano) }\end{array}$ \\
\hline Cinema & & & & \\
\hline Teatro & & & & \\
\hline Concerto & & & & \\
\hline Show & & & & \\
\hline Dança & & & & \\
\hline
\end{tabular}

23.1 Para você, qual o principal motivo para não frequentar estas atividades:

[ ] falta de interesse [ ] falta de tempo [ ] falta de alguém que possa levá-lo [ ] falta de dinheiro [ ] falta de informação sobre a existência dos espetáculos [ ] não sabe a razão

24. Você já visitou algum museu virtual (museu na internet)? [ ] Sim [ ]Não 
25. O que você mais faz no seu tempo livre (fora da escola)?

[ ] elabora o para casa [ ] pratica algum esporte [ ] anda de bicicleta

[ ] brinca [ ] usa redes sociais (Facebook, Twitter, Instagram, WhatsApp)

[ ] navega na Internet [ ] usa jogos eletrônicos [ ] assiste à TV

[ ] participa de práticas religiosas [ ] ajuda em tarefas domésticas

[ ] trabalha [ ] outros:

26. Você gosta de morar em Belo Horizonte?

[ ] Não gosto [ ] Sou indiferente [ ] Gosto pouco [ ] Gosto muito 26.1 Por quê?

27. Você participa de alguma associação (EXPLICAR) em sua comunidade? [ ] Sim [ ] Não (pule para a 28)

27.1 Qual?

28. Considerando as melhorias necessárias em sua cidade, ordene de 1 a

5, de acordo com importância dos aspectos que mais precisam melhorar?

[ ] Limpeza urbana

[ ] Transporte público

[ ] Saúde

[ ] Uso de praças, parques, museus, centros culturais, centros esportivos, etc.

[ ] Educação

Parte 3: Sobre o CL

29. Você já ouviu falar do Circuito Liberdade?

[ ] Sim [ ] Não (pule para a 31)

29.1 Como você ficou sabendo a respeito do Circuito Liberdade?

[ ] Passando em frente ao circuito [ ] Visitando outros museus ou circuitos culturais [ ] Pela televisão [ ] Pelo rádio [ ] Através de panfletos, cartazes, outdoors [ ] Lendo jornais ou revistas [ ] No guia turístico [ ] Por recomendação de amigos [ ] Por recomendação de professores [ ] Por recomendação de familiares [ ] Pela sinalização de rua [ ] Pela internet [ ] Outra fonte. Qual?

30. Você já visitou o Circuito Liberade por conta própria? ［ ] Sim ～] Não

31. Alguns alunos da sua escola visitaram este Circuito Cultural, por que você não fez a visita com a escola?

[ ] estava doente [ ] doença na família [ ] estava viajando

[ ] não ficou sabendo [ ] não quis [ ] não tinha vaga

[ ] outro motivo:

Obrigada(o)! 
